\title{
Pengaruh bahan water repellent terhadap morfologi dan sifat-sifat fisika pada pembuatan kulit atasan sepatu ramah lingkungan
}

\section{The influence of water repellent agent on morphology and physical properties in the production of eco-friendly upper leather}

\author{
Prayitno*, Emiliana Kasmudjiastuti, Dona Rahmawati \\ Balai Besar Kulit, Karet, dan Plastik, Jl. Sokonandi No. 9 Yogyakarta 55166, Indonesia \\ *Penulis korespondensi. Telp.: +62 274 512929, 563939; Fax.: +62 274563655 \\ E-mail: prayitno_bbkkp@yahoo.com
}

Diterima: 29 Maret 2016 Direvisi: 8 September 2016 Disetujui: 8 September 2016

\begin{abstract}
The term of eco-friendly leather can be interpreted as chrome-free tanned leather. Recently, almost $80 \%$ of leather is tanned using chrome tanning agent because of the ease in processing and excellence of the physical properties. Nevertheless, people nowadays want an eco-friendly leather product. Vegetable tanning materials can be said as eco-friendly tanning material because their waste degrades easily. One of the weaknesses in the use of vegetable tanning is a high water absorption capability. In this research used a water repellent material that has the properties to suppress the ability of water absorption. The purpose of the research was to determine the effect of water repellent on physical properties and morphology of leather tanned by vegetable tanning materials. Because one of the weaknesses in the vegetable tanning is its high water absorption capability, in this research, water repellent was used and varied by $5 ; 7.5 ; 10 ; 12.5$; and $15 \%$. Physical properties obtained were compared with analysis of variance with the significance level of $95 \%$. The water repellent increased from $5 \%$ to $15 \%$. The results showed a decrease in water absorption capability from $77.6 \%$ to $65.39 \%$, tearing strength from 41.64 to $20.05 \mathrm{~kg} /$ $\mathrm{cm}$, tensile strength from 227.10 to $163.53 \mathrm{~kg} / \mathrm{cm}^{2}$, and elongation at break from 57.11 to $49.68 \%$, strong swelling and WVA have no significant changes, while for WVP, the maximum use of water repellent at $12.5 \%$. SEM results indicate the presence of a thin layer on the leather fiber that can inhibit the absorption of water.
\end{abstract}

Keywords: water repellent, upper leather, vegetable tanning, water absorption.

\begin{abstract}
ABSTRAK
Istilah "Ramah Lingkungan" untuk kulit dapat diartikan sebagai kulit tersamak yang bebas krom. Hampir 80\% penyamakan saat ini menggunakan krom, karena kemudahan dalam proses dan keunggulan dalam sifat-sifat fisis kulit samaknya. Namun saat ini masyarakat menghendaki suatu produk yang ramah lingkungan. Bahan penyamak nabati dapat dikatakan sebagai bahan penyamak ramah lingkungan sebab limbah produknya mudah terdegradasi. Salah satu kelemahan dalam penggunaan samak nabati adalah kemampuan penyerapan airnya yang tinggi. Pada penelitian ini digunakan bahan water repellent yang mempunyai sifat untuk menekan kemampuan penyerapan air. Maksud dari penelitian adalah untuk mengetahui pengaruh dari water repellent pada penyerapan air, sifat-sifat fisis dan morfologi kulit yang disamak dengan bahan penyamak nabati. Penelitian dilakukan dengan memvariasi jumlah water repellent dari $5 ; 7,5 ; 10 ; 12,5$ dan $15 \%$. Sifat-sifat fisis yang didapatkan kemudian dibandingkan dengan analisis sidik ragam dengan taraf kepercayaan $95 \%$. Hasil penelitian menunjukkan adanya penurunan dalam sifat penyerapan airnya walaupun tidak signifikan dari 77,6\% menjadi 65,39\%, penurunan kuat sobek dari 41,64 menjadi $20,05 \mathrm{~kg} / \mathrm{cm}$, kuat tarik dari 227,10 menjadi $163,53 \mathrm{~kg} / \mathrm{cm}^{2}$ dan kemuluran dari 57,11 menjadi 49,68\% masing-masing untuk water repellent berturut-turut 5 dan $15 \%$, kuat bengkuk dan WVA tidak ada perubahan yang signifikan, sedangkan untuk WVP maksimum terjadi pada penggunaan water repellent $12,5 \%$. Hasil SEM menunjukkn adanya lapisan tipis pada serat kulit yang dapat menghambat penyerapan air.
\end{abstract}

Kata kunci: water repellent, kulit atasan sepatu, samak nabati, penyerapan air. 


\section{PENDAHULUAN}

Proses penyamakan kulit secara konvensional dilakukan melalui tiga tahapan proses utama yaitu proses beamhouse, proses tanning, dan post tanning. Proses beamhouse adalah proses dari pencucian kulit mentah sampai dengan pengasaman kulit pelt untuk membuka struktur sel kulit sebagai persiapan untuk dilakukan proses pemasukan zat penyamak; proses tanning yaitu proses memasukkan bahan penyamak yang dapat membentuk ikatan silang dengan kolagen sehingga menjadikan kulit yang tidak mudah terdegradasi oleh mikroba; dan post tanning merupakan tahap proses penyamakan untuk mendapatkan sifat-sifat kulit sesuai dengan peruntukannya. Post tanning meliputi prosesproses retanning, dyeing, dan fatliquoring serta proses finishing untuk meningkatkan penampilan dari kulit tersamak dengan pementangan, pengecatan tutup, dan pengepresan (Ali et al., 2013; Ozgunay et al., 2007; Covington, 2009).

Tiap tahapan proses penyamakan memerlukan bahan kimia dan air dalam jumlah banyak sehingga menghasilkan banyak limbah. Pengolahan 1 ton kulit mentah akan menghasilkan $40-50 \mathrm{~m}^{3}$ limbah cair (Ramanujam et al., 2010; Ozgunay et al., 2007). Dari jumlah tersebut hampir $98 \%$ dihasilkan dari keseluruhan proses penyamakan kulit, terutama pada proses beamhouse. Pada proses tanning, terdapat banyak bahan yang dapat digunakan sebagai bahan penyamak. Nasr et al. (2013) menyatakan bahwa dari beberapa proses penyamakan yang banyak digunakan saat ini adalah proses penyamakan dengan bahan penyamak mineral dan bahan penyamak nabati.

Salah satu bahan penyamak mineral yang digunakan adalah bahan penyamak krom. Sampai saat ini bahan penyamak krom merupakan bahan penyamak yang digunakan oleh sebagian besar industri penyamakan kulit (Mahdi et al., 2009). Mahdi et al. (2009) menyatakan bahwa hampir $80-85 \%$ industri penyamak dunia menggunakan bahan penyamak krom, hal tersebut dikarenakan keunggulan-keunggulan kulit yang disamak dengan krom meliputi kemudahan proses, suhu kerut, kuat tarik, kelemasan, dan softness kulit samak yang dihasilkan (Nashy et al., 2010). Di sisi lain penggunaan bahan penyamak krom juga memberikan kerugian terkait dengan limbah logam berat yang dihasilkan. Limbah krom merupakan limbah logam berat yang dikategorikan sebagai limbah B3.
Upaya-upaya untuk menggantikan samak mineral krom telah banyak dilakukan. Musa and Aravindhan (2011) menggunakan krom dengan daya adsorbsi tinggi, namun belum dapat juga menangani limbah krom yang dikeluarkan. Mutlu et al. (2014) menggunakan bahan penyamak titanium yang didapat dari limbah industri logam, Yan et al. (2008) dan Li et al. (2011) menggunakan bahan-bahan ukuran nano baik dalam bentuk bahan kimia tunggal seperti silikat maupun komposit untuk menyamak kulit sebagai pengganti krom, namun dalam penerapannya dirasa masih banyak kesulitan terutama untuk para pengrajin. Mazumder et al. (2006) menyatakan bahwa penyamakan dengan bahan penyamak nabati dapat menggantikan bahan penyamak krom pada kondisi dimana adanya krom tidak dikehendaki seperti limbah yang terbentuk, pada penyamakan nabati akan terjadi reaksi kimia membentuk ikatan silang antara molekul tanin dengan serat kolagen. Castell et al. (2013) menggunakan bahan penyamak nabati dari tumbuhan Tara untuk menggantikan bahan penyamak krom. Sedangkan Koloka and Moreki (2011) menyatakan bahwa penyamakan dengan bahan penyamak nabati merupakan penyamakan yang akrab lingkungan karena limbah yang dihasilkan dapat terdegradasi oleh mikroorganisme.

Bahan penyamak nabati mempunyai keunggulan dalam kepadatan kulit, kekuatan sobek, dan permeabilitas terhadap udara sehingga dapat digunakan untuk mengganti bahan penyamak krom. Bahan penyamak nabati yang banyak digunakan adalah quebracho dan mimosa yang mempunyai kadar tanin berturut-turut 35\% dan 18\% dan dapat digunakan untuk membuat kulit garmen, jok, dan atasan sepatu (Nasr et al., 2013). Pada pembuatan kulit untuk atasan sepatu dengan samak nabati dijumpai adanya beberapa kekurangan yaitu penyerapan air yang tinggi (Widari et al., 2013) dan suhu kerut yang rendah $84 \pm 1{ }^{\circ} \mathrm{C}$ (Musa \& Aravindhan, 2011) dibandingkan dengan krom yang mencapai $100^{\circ} \mathrm{C}$, menyebabkan rendahnya sifat-sifat fisis kulit tersamak. Sehingga pada pembuatan kulit atasan sepatu samak nabati untuk mengurangi penyerapan air yang tinggi perlu digunakan bahan water repellent dan untuk meningkatkan sifat-sifat fisis dapat dikombinasi dengan bahan retanning non krom. Bahan water repellent berupa bahan peminyakan yang dapat digunakan (Jankauskaite et al., 2014) diantaranya jenis flourinated polymer. 


\section{BAHAN DAN METODE \\ Bahan Penelitian}

Kulit sapi pikel, garam, natrium formiat, Tanigan $\mathrm{OC}$, natrium bicarbonat, mimosa, neutralising syntan, resin akrilik, Tanicor SGN, Sincal MS, cat dasar, Derminol SBJ, Derminol SPE, anti jamur, asam formiat, Hexafor, RA 2, RU 3906, BI 372 , FI 11250, penetrator, pigment, lacque netral, thiner super, dan KS.

\section{Peralatan Penelitian}

Drum penyamakan, alat pengetaman, alat staking, alat pementangan, dan alat plating serta alat uji: flexing, kuat sobek, kuat tarik dan kemuluran, penyerapan air, permeabilitas uap air (water vapour permeability/WVP), dan permeabilitas air (water vapour absorbtion/WVA). Morfologi kulit hasil penelitian dianalisis dengan scanning electron microscope (SNE $3200 \mathrm{M}$, Korea) dengan tebal potongan melintang 1,2 $\mathrm{mm}$, kondisi elektron heating voltage $20 \mathrm{kV}$, beam spot $-5,0 \mathrm{~mm}$, magnification $67 \mathrm{x}$, work distance $6 \mathrm{~mm}$, vacuum $80 \mathrm{~Pa}$ dengan detektor LFD.

\section{Metode Penelitian}

Penelitian dilakukan dengan memvariasi bahan penyamak dengan bahan penyamak nabati dan tiap jenis bahan digunakan water repellent yang divariasi $5 ; 7,5 ; 10 ; 12,5$; dan $15 \%$ hasilnya dianalisis untuk mengetahui pengaruh dari bahan water repellent terhadap morfologi kulit tersamak dan sifat-sifat fisisnya dengan skema proses seperti disajikan pada Tabel 1.

Analisis kimia dan fisis kulit atasan sepatu meliputi uji flexing, kuat sobek, kuat tarik dan kemuluran, penyerapan air, WVP, WVA, dan SEM.

Data yang diperoleh dari hasil pengujian fisis dianalisis secara statistik dengan analisis varian untuk setiap perlakuan dilanjutkan dengan analisis LSD derajat signifikansi $95 \%$

\section{HASIL DAN PEMBAHASAN \\ Hasil Pengujian Fisis}

Hasil pengujian fisis kulit hasil penelitian disajikan seperti pada Tabel 2.

\section{Flexing}

Hasil uji flexing menunjukkan bahwa dengan formulasi penelitian, semua perlakuan memenuhi persyaratan kulit atasan sepatu Nappa berdasarkan SNI 4901:2009 Kulit bagian atas alas kakikulit Nappa (BSN, 2009). Hal ini menunjukkan bahwa formula hasil penelitian memberikan kelemasan yang baik. Salah satu kelemahan pada samak nabati adalah fleksibilitas yang kurang sehingga perlu adanya bahan peminyakan yang cukup. Penambahan bahan peminyakan berupa Derminol SBJ yang merupakan fatliquor sintetik dan Derminol SPE yang merupakan fatliquor alami ditambah dengan bahan water repellent $5-15 \%$ akan memberikan sifat kelemasan yang baik pada kulit. Nasr et al. (2013) menyatakan bahwa penyamakan kulit dengan menggunakan samak nabati $12 \%$ akan menghasilkan kulit yang kadar lemaknya antara $10-13 \%$ yang berarti memberikan kelemasan yang cukup pada kulit tersamak. Masuknya minyak ke dalam kulit dipengaruhi oleh proses fatliquoring, seperti suhu proses yang dipertahankan pada $50-60^{\circ} \mathrm{C}$ dan $\mathrm{pH}$ netral, suhu yang terlalu rendah dapat menaikkan konsistensi sehingga sulit terpenetrasi dalam kulit, sebaliknya suhu tinggi menyebabkan reaktifitas kolagen dan fatliquor meningkat, sehingga menyebabkan penetrasi minyak menurun (Prayitno, 2014).

\section{Kuat sobek}

Hasil uji kuat sobek dari kulit atasan sepatu ramah lingkungan dengan bahan penyamak nabati disajikan pada Tabel 2 dan Gambar 1. Terjadinya penurunan kuat sobek pada kenaikan water repellent dimungkinkan karena ketidakseragaman kulit wetblue yang disamak atau kemungkinan bahan water repellent ini juga melapisi serat-serat kolagen sehingga daya ikatnya akan berkurang. Hasil perhitungan statistik dengan taraf kepercayaan 95\% disajikan pada Tabel 3 .

Dari analisis sidik ragam diperoleh $\mathrm{F}_{\mathrm{ht}}=3,51$ $\geq \mathrm{F}_{\mathrm{tbl}=3.48}$ berarti ada beda nyata dari perlakuan, kemudian dilanjutkan dengan uji Duncan untuk mengetahui perbedaan setiap perlakuan seperti disajikan pada Tabel 4. Dari hasil uji Duncan terlihat bahwa meningkatnya jumlah water repellent yang ditambahkan akan menurunkan kuat sobek kulit samak yang dihasilkan. Perbedaan nyata terjadi pada penggunaan water repellent 7,5; 12,5: dan $15 \%$ dengan penggunaan water repellent $5 \%$. Pada penggunaan water repellent $10 \%$ tidak menunjukkan adanya beda nyata, hal tersebut dimungkinkan karena kurang seragamnya contoh kulit mentah yang digunakan.

\section{Kuat tarik dan kemuluran}

Hasil uji kuat tarik dan kemuluran kulit atasan sepatu samak nabati disajikan pada Tabel 2 dan pada Gambar 2 dan 3. Dari grafik terlihat adanya 
Tabel 1. Skema proses penyamakan kulit atasan sepatu samak nabati.

\begin{tabular}{|c|c|c|c|c|c|}
\hline No & Proses & Bahan & $\%$ & Suhu & Perlakuan \\
\hline 1 & Bahan baku & Kulit pikel sapi & 100 & & Tebal $0,8-1,2$ \\
\hline \multirow[t]{2}{*}{2} & Wetting back & Air & 300 & & \\
\hline & & Garam & 10 & & Putar 20 mnt, drain, cuci \\
\hline \multirow[t]{6}{*}{3} & Pre-tanning & Kulit pikel sapi & 100 & & \\
\hline & & Air & 100 & & Putar drum $10 \mathrm{mnt}$ \\
\hline & & Garam & 8 & & \\
\hline & & $\mathrm{Na}$ formiat & 1 & & \\
\hline & & Tanigan OC & 5 & & Putar drum 60 mnt, \\
\hline & & $\mathrm{NaHCO}_{3}$ & 0,5 & & $\begin{array}{l}\text { Aduk } 3 \times 15 \text { mnt, lanjutkan } 60 \text { menit, } \\
\text { check pH.4,5-5, over night }\end{array}$ \\
\hline 4 & Shaving & Kulit pretanning & 100 & & Ketebalan $1,2 \mathrm{~mm}$ \\
\hline \multirow[t]{5}{*}{5} & Tanning & Kulit shaving & 100 & & \\
\hline & & Air & 100 & & Putar $10 \mathrm{mnt}$, cek $8^{\circ} \mathrm{Be}$ \\
\hline & & $\mathrm{Na}$ formiat & 1 & & Putar 10 mnt, \\
\hline & & Mimosa & 25 & & Putar $30 \mathrm{mnt}$, cek pH \\
\hline & & Neutralizing syntan & 2 & & Putar $60 \mathrm{mnt}$, pH 5, over night \\
\hline \multirow[t]{7}{*}{6} & Retanning/ & Air & 200 & & \\
\hline & Netralisasi & FA & 0,4 & & Putar $15 \mathrm{mnt}$ \\
\hline & & Na. Formiat & 1,5 & & Putar $30 \mathrm{mnt}$ \\
\hline & & Soda kue & 1,25 & & Putar $30 \mathrm{mnt}$ \\
\hline & & Syntan neutralisir & 2 & & Putar 15 mnt, 2x \\
\hline & & & & & Putar 15 mnt, $3 \mathrm{x}$ \\
\hline & & & & & Putar 30 mnt, cek pH=5, drain \\
\hline 7 & Pencucian & Air & 400 & & Putar 5 mnt, $2 \mathrm{x}$, drain \\
\hline \multirow[t]{4}{*}{8} & Penyamakan & Air & 100 & $45^{\circ} \mathrm{C}$ & \\
\hline & ulang & Resin akrilik & 4 & & Putar $45 \mathrm{mnt}$ \\
\hline & & & 3 & & Putar 45 mnt, drain \\
\hline & & Tanicor SGN & & & \\
\hline \multirow[t]{3}{*}{9} & Pewarnaan & Air & 100 & $50^{\circ} \mathrm{C}$ & \\
\hline & Dasar & Sincal. MS & 1 & & Putar 5 mnt \\
\hline & & Cat dasar & 2 & & Putar $60 \mathrm{mnt}$ \\
\hline \multirow[t]{4}{*}{10} & Peminyakan & Air & 50 & $60^{\circ} \mathrm{C}$ & \\
\hline & & Derminol SBJ & 3 & & \\
\hline & & Derminol SPE & 3 & & \\
\hline & & Anti jamur & 0,1 & & Putar $90 \mathrm{mnt}$ \\
\hline \multirow[t]{2}{*}{11} & Fiksasi & $\mathrm{HCOOH}$ & $0.5 \mathrm{x}$ & & Putar@15 mnt, \\
\hline & & Hexaflor L & var & & $\begin{array}{l}\text { Putar } 20 \text { mnt, drain, bilas, seting out. } \\
\text { Overnight, miling, staking }\end{array}$ \\
\hline \multirow[t]{2}{*}{12} & Wetting back & Air & 200 & & \\
\hline & & Wetting & 1 & & Putar 30 mnt, cuci \\
\hline \multirow[t]{8}{*}{13} & Finishing & Soft acrylic, Urethane, & $200 \mathrm{gr}$ & & \\
\hline & & Med-soft acrylic & $50 \mathrm{gr}$ & & \\
\hline & & Wax filler & $50 \mathrm{gr}$ & & \\
\hline & & penetrator & $25 \mathrm{gr}$ & & \\
\hline & & Pigment & $25 \mathrm{gr}$ & & \\
\hline & & Hexaflor & $125 \mathrm{gr}$ & & \\
\hline & & Air & $20 \mathrm{gr}$ & & Aduk hingga larut, spray \\
\hline & & & $525 \mathrm{gr}$ & & \\
\hline \multirow[t]{3}{*}{14} & Top Coating & Lacque & $400 \mathrm{gr}$ & & \\
\hline & & Solvent & $600 \mathrm{gr}$ & & \\
\hline & & $\mathrm{KS}$ & $20 \mathrm{gr}$ & & Aduk rata, spray, angin-anginkan \\
\hline
\end{tabular}


Tabel 2. Rerata hasil uji kulit atasan sepatu samak nabati.

\begin{tabular}{|c|c|c|c|c|c|c|c|}
\hline \multirow{2}{*}{ No. } & \multirow{2}{*}{ Macam uji } & \multicolumn{5}{|c|}{ Water repellent $(\%)$} & \multirow{2}{*}{$\begin{array}{c}\text { Syarat } \\
\text { SNI }\end{array}$} \\
\hline & & 5 & 7,5 & 10 & 12,5 & 15 & \\
\hline 1 & Flexing (20.000 kali) & $\begin{array}{c}\text { Tidak } \\
\text { retak }\end{array}$ & $\begin{array}{r}\text { Tidak } \\
\text { retak }\end{array}$ & $\begin{array}{r}\text { Tidak } \\
\text { retak }\end{array}$ & $\begin{array}{l}\text { Tidak } \\
\text { retak }\end{array}$ & $\begin{array}{r}\text { Tidak } \\
\text { retak }\end{array}$ & $\begin{array}{l}\text { Tidak } \\
\text { retak }\end{array}$ \\
\hline 2 & Kuat sobek, $\mathrm{kg} / \mathrm{cm}$ & 41,64 & 24,70 & 28,22 & 27,55 & 20,05 & $\geq 30,59$ \\
\hline 3 & Penyerapan air, \% & 77,96 & 74,44 & 66,74 & 64,40 & 65,39 & $\leq 70$ \\
\hline 4 & Kuat tarik, N/mm & 227,10 & 167,19 & 203,98 & 157,86 & 163,53 & $\geq 203,94$ \\
\hline 5 & Kemuluran, (\%) & 57,11 & 52,04 & 57,32 & 46,65 & 49,68 & $\leq 60$ \\
\hline 6 & WVP, $\mathrm{mg} / \mathrm{cm}^{2} / \mathrm{jam}$ & 5,14 & 5,66 & 6,59 & 8,26 & 5,96 & $\geq 0,8$ \\
\hline 7 & WVA, $\mathrm{mg} / \mathrm{cm}^{2}$ & 11,35 & 12,27 & 14,97 & 13,63 & 4,27 & $\geq 5$ \\
\hline
\end{tabular}

Tabel 3. Analisis sidik ragam.

\begin{tabular}{lccccc}
\hline \multicolumn{1}{c}{$\begin{array}{c}\text { Sumber } \\
\text { Keragaman }\end{array}$} & d.b & SS & MS & $\mathrm{F}_{\text {hit }}$ & $\mathrm{F}_{\text {tbl }}$ \\
\hline $\begin{array}{l}\text { Perlakuan } \\
\text { Error }\end{array}$ & $\mathrm{n}-1)=4$ & $\mathrm{SS}_{\mathrm{t}}=777.86$ & $\mathrm{~S}_{\mathrm{t}}{ }^{2}=194.46$ & 3,51 & 3,48 \\
\hline
\end{tabular}

Tabel 4. Analisis LSD kuat sobek.

\begin{tabular}{cccc}
$\mathrm{F}_{\mathrm{ht}=3,51} \geq \mathrm{F}_{\mathrm{tbl}=3.48}$ & Notasi LSD 5\% $=13,52$ \\
\hline WR (5) & Total & Rerata & Notasi LSD 5\% \\
\hline 15 & 60,16 & 20,05 & $\mathrm{~A}$ \\
7,5 & 74,11 & 24,70 & $\mathrm{a} \mathrm{b}$ \\
12,5 & 82,66 & 27,55 & $\mathrm{Abc}$ \\
10 & 84,66 & 28,22 & $\mathrm{Abcd}$ \\
5 & 124,91 & 41,64 & $\mathrm{~d} \mathrm{e}$ \\
\hline
\end{tabular}

kecenderungan kuat tarik yang menurun dengan meningkatnya kadar water repellent. Musa and Aravindhan (2011) menyatakan kulit samak dengan bahan nabati memberikan kuat tarik $210 \pm 3$ $\mathrm{kg} / \mathrm{cm}^{2}$, sesuai dengan hasil penelitian dengan $w a-$ ter repellent $5 \%$.

Penurunan kuat tarik dengan meningkatnya penggunaan water repellent kemungkinan di- sebabkan karena kurang seragamnya kulit wetblue untuk penelitian, atau kemungkinan disebabkan water repellent mengikat serabut-serabut kolagen sehingga mengurangi ikatan antar kolagen dan menurunkan kuat tariknya.

Hasil uji kemuluran menunjukkan adanya pola yang sama dengan kuat tarik, semua memenuhi persyaratan standard kulit atasan sepatu

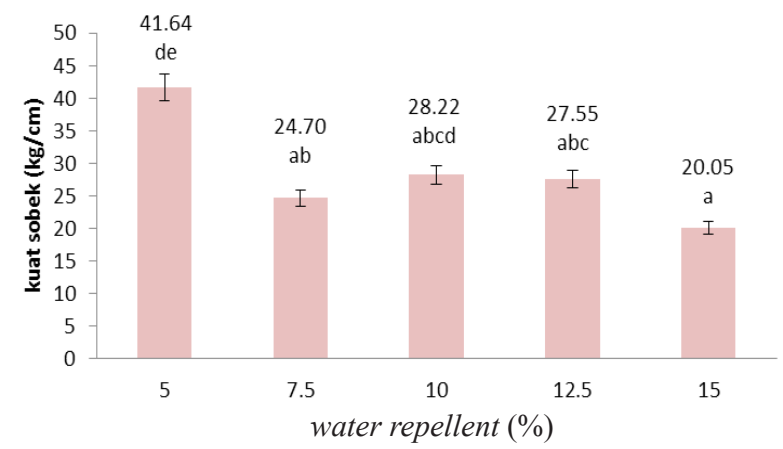

Gambar 1. Kuat sobek kulit atasan sepatu samak nabati dengan perbedaan kadar water repellent.

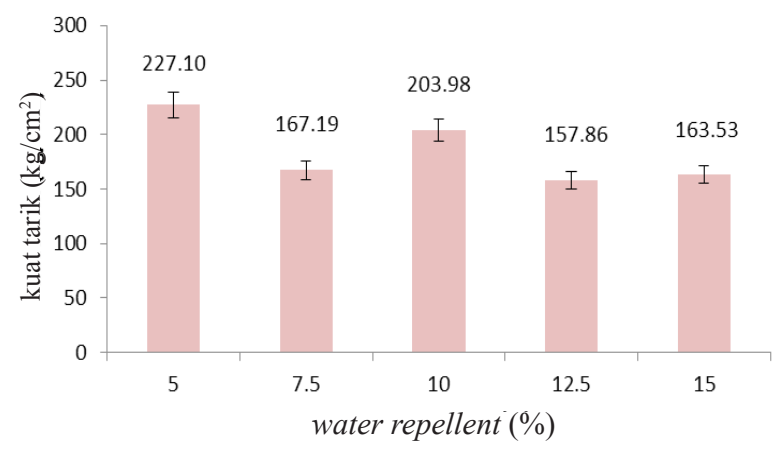

Gambar 2. Kuat tarik kulit atasan sepatu samak nabati dengan perbedaan kadar water repellent. 
Tabel 5. Analisis sidik ragam kuat tarik kulit atasan sepatu samak nabati.

\begin{tabular}{lccccc}
\hline $\begin{array}{c}\text { Sumber } \\
\text { Keragaman }\end{array}$ & d.b & SS & MS & $\mathrm{F}_{\text {hit }}$ & $\mathrm{F}_{\mathrm{tbl}}$ \\
\hline Perlakuan & $(\mathrm{n}-1)=4$ & $\mathrm{SS}_{\mathrm{t}}=10924,53$ & $\mathrm{~S}_{\mathrm{t}}{ }^{2}=2731,13$ & 0,37 & 3,48 \\
Error & $\mathrm{n}(\mathrm{k}-1)=10$ & $\mathrm{SS}_{\mathrm{e}}=74499,38$ & $\mathrm{~S}_{\mathrm{p}}{ }^{2}=7449,94$ & & \\
\hline
\end{tabular}

Tabel 6. Analisis sidik ragam kemuluran kulit atasan sepatu samak nabati.

\begin{tabular}{lccccc}
\hline $\begin{array}{c}\text { Sumber } \\
\text { Keragaman }\end{array}$ & d.b & SS & MS & $\mathrm{F}_{\text {hit }}$ & $\mathrm{F}_{\text {tbl }}$ \\
\hline Perlakuan & $(\mathrm{n}-1)=4$ & $\mathrm{SS}_{\mathrm{t}}=260,50$ & $\mathrm{~S}_{\mathrm{t}}{ }^{2}=65,13$ & 0,86 & 3,48 \\
Error & $\mathrm{n}(\mathrm{k}-1)=10$ & $\mathrm{SS}_{\mathrm{e}}=756,54$ & $\mathrm{~S}_{\mathrm{p}}{ }^{2}=75,65$ & & \\
\hline
\end{tabular}

Tabel 7. Analisis sidik ragam penyerapan air.

\begin{tabular}{lccccc}
\hline $\begin{array}{c}\text { Sumber } \\
\text { Keragaman }\end{array}$ & d.b & SS & MS & $\mathrm{F}_{\text {hit }}$ & $\mathrm{F}_{\mathrm{tbl}}$ \\
\hline Perlakuan & $(\mathrm{n}-1)=4$ & $\mathrm{SS}_{\mathrm{t}}=438,66$ & $\mathrm{~S}_{\mathrm{t}}{ }^{2}=109,67$ & 0,24 & 3,48 \\
Error & $\mathrm{n}(\mathrm{k}-1)=10$ & $\mathrm{SS}_{\mathrm{e}}=4654,41$ & $\mathrm{~S}_{\mathrm{p}}{ }^{2}=465,44$ & & \\
\hline
\end{tabular}

Nappa berdasarkan SNI 4901:2009 Kulit bagian atas alas kaki-kulit Nappa. Kemuluran kulit yang disamak dengan nabati $42 \pm 1,58 \%$ (Musa \& Aravindhan, 2011).

Uji statistik menunjukkan tidak adanya perbedaan pada setiap perlakuan. Analisis sidik ragam kuat tarik maupun kemuluran seperti yang disajikan pada Tabel 5 dan Tabel 6 tidak menunjukkan adanya perbedaan nyata pada setiap perlakuan $\left(\mathrm{F}_{\mathrm{ht}=0,37}\right.$ dan $\mathrm{F}_{\mathrm{ht}=0,86}$ lebih kecil dari $\left.\mathrm{F}_{\mathrm{tbl}=3,48}\right)$.

\section{Penyerapan air}

Hasil uji penyerapan air kulit atasan sepatu samak nabati dengan penambahan water repellent seperti disajikan pada Tabel 2 dan Gambar 4.

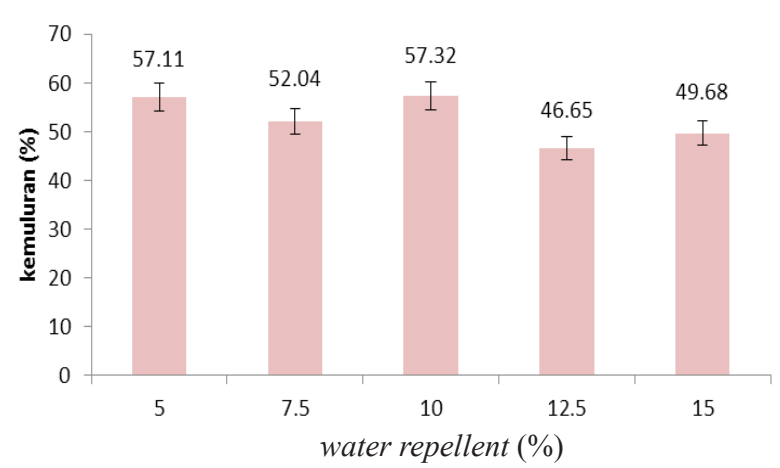

Gambar 3. Kemuluran kulit atasan sepatu samak nabati dengan perbedaan kadar water repellent.
Dari grafik terlihat meningkatnya penggunaan water repellent akan menurunkan kemampuan absorpsi air dari kulit tersamak. Namun dari analisis sidik ragam dengan taraf kepercayaan 95\% seperti disajikan pada Tabel 7.

Hasil analisis sidik ragam $\mathrm{F}_{\mathrm{ht}=0,24} \leq \mathrm{F}_{\mathrm{tbl}=3,48}$ menunjukkan adanya penurunan yang tidak berbeda nyata pada setiap perlakuan. Hal tersebut dimungkinkan karena pada penyamakan dengan bahan penyamak nabati yang salah satu kelemahannya adalah tingginya kemampuan penyerapan air (Widari et al., 2013) dan suhu kerutnya yang rendah (Musa \& Aravindhan, 2011), fungsi water repellent yang akan memberikan lapisan untuk penyerapan air tidak dapat meliputi seluruh

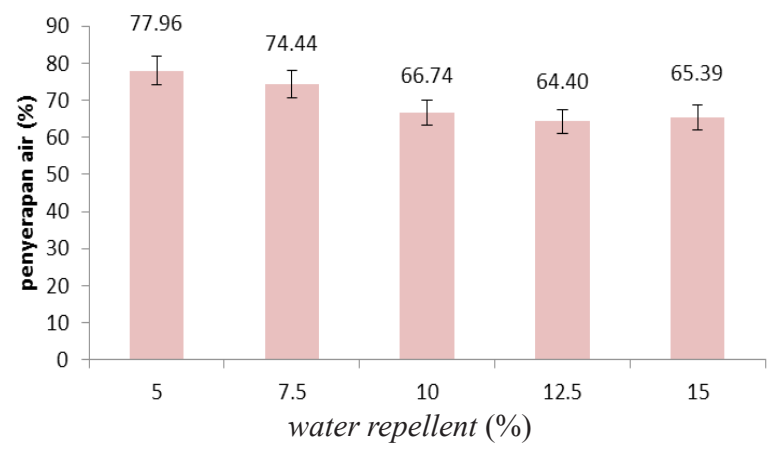

Gambar 4. Penyerapan air kulit atasan sepatu samak nabati dengan perbedaan kadar water repellent. 
Tabel 8. Analisis sidik ragam permeabilitas uap air.

\begin{tabular}{lccccc}
\hline $\begin{array}{c}\text { Sumber } \\
\text { Keragaman }\end{array}$ & d.b & SS & MS & $\mathrm{F}_{\text {hit }}$ & $\mathrm{F}_{\text {tbl }}$ \\
\hline Perlakuan & $(\mathrm{n}-1)=4$ & $\mathrm{SS}_{\mathrm{t}}=17,41$ & $\mathrm{~S}_{\mathrm{t}}{ }^{2}=4,35$ & 3,62 & 3,48 \\
Error & $\mathrm{n}(\mathrm{k}-1)=10$ & $\mathrm{SS}_{\mathrm{e}}=12,03$ & $\mathrm{~S}_{\mathrm{p}}{ }^{2}=1,20$ & & \\
\hline
\end{tabular}

Tabel 9. Analisis LSD permeabilitas uap air.

\begin{tabular}{cccc}
$\mathrm{F}_{\mathrm{ht}=3,51} \geq \mathrm{F}_{\mathrm{tbl}=3.48}$ & \multicolumn{2}{c}{ Notasi LSD 5\%= 13,52} \\
\hline $\mathrm{WR}(5)$ & Total & Rerata & Notasi LSD 5\% \\
\hline 5 & 15,42 & 5,14 & $\mathrm{a}$ \\
7,5 & 16,99 & 5,66 & $\mathrm{a} \mathrm{b}$ \\
15 & 17,89 & 5,96 & $\mathrm{abc}$ \\
10 & 19,79 & 6,59 & $\mathrm{abcd}$ \\
12 & 24,79 & 8,26 & $\mathrm{~d} \mathrm{e}$ \\
\hline
\end{tabular}

serat kulit tersamak, atau dimungkinkan karena mimosa yang digunakan sebagai bahan penyamak banyak mengandung zat gula yang dapat menghasilkan asam galat yang menyebabkan kulit mudah membengkak (Nasr et al., 2013) yang akan meningkatkan penyerapan air. Penelitian yang telah dilakukan tanpa penambahan water repellent menghasilkan besarnya penyerapan air $254,61 \%$ (Nasr et al., 2013).

\section{WVP dan WVA}

Tujuan utama penggunaan water repellent adalah untuk mengurangi kapasitas kulit tersamak dalam penyerapan air, terutama sekali pada produk-produk alas kaki yang banyak bersinggungan dengan air terlebih bila dikehendaki untuk penggunaannya dalam suhu dingin. Namun demikian, untuk kenyamanan pakai harus juga diperhatikan breathability dari kulit yang dapat dilihat dari besarnya permeabilitas uap air (WVP)

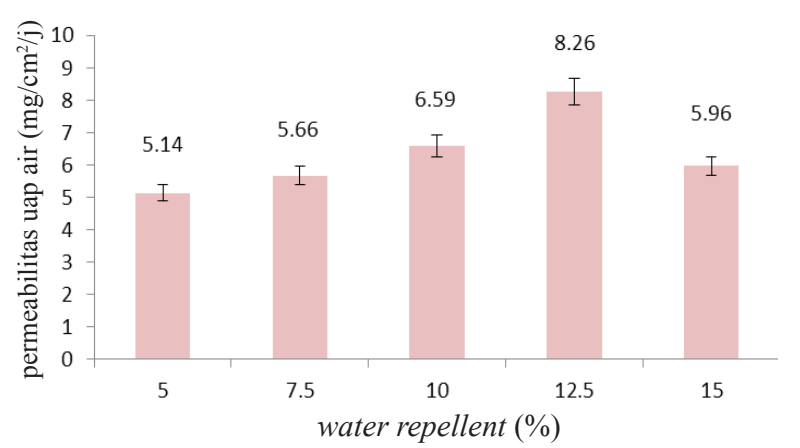

Gambar 5. Permeabilitas uap air kulit atasan sepatu samak nabati dengan perbedaan kadar water repellent. dan penyerapan uap airnya (WVA). Hasil uji kulit atasan sepatu samak nabati dengan water repellent untuk WVP dan WPA adalah seperti disajikan pada Gambar 5 dan Gambar 6. Dari grafik pada Gambar 5 terlihat adanya kenaikan permeabilitas dari kulit atasan sepatu yang disamak nabati dengan meningkatnya penggunaan water repellent sampai dengan $12,5 \%$ yang kemudian terjadi penurunan pada penggunaan $15 \%$. Semua perlakuan memenuhi persyaratan kulit atasan sepatu yaitu $\geq 0,8 \mathrm{mg} / \mathrm{cm}^{2} / \mathrm{jam}$.

Dari analisis sidik ragam dengan taraf kepercayaan 95\% seperti disajikan pada Tabel 8 terlihat perbedaannya pada perlakuan $\left(\mathrm{F}_{\mathrm{ht}=3,62} \geq \mathrm{F}_{\mathrm{tbl}=3,48}\right)$ dan setelah dilanjutkan dengan uji Duncan seperti disajikan pada Tabel 9 perbedaan nyata terjadi pada penggunaan water repellent $5 ; 7,5 ; 15 \%$ dengan penggunaan water repellent $12 \%$. Penggunaan water repellent optimum sebesar $12 \%$. Penurunan WVP pada penggunaan water repellent setelah

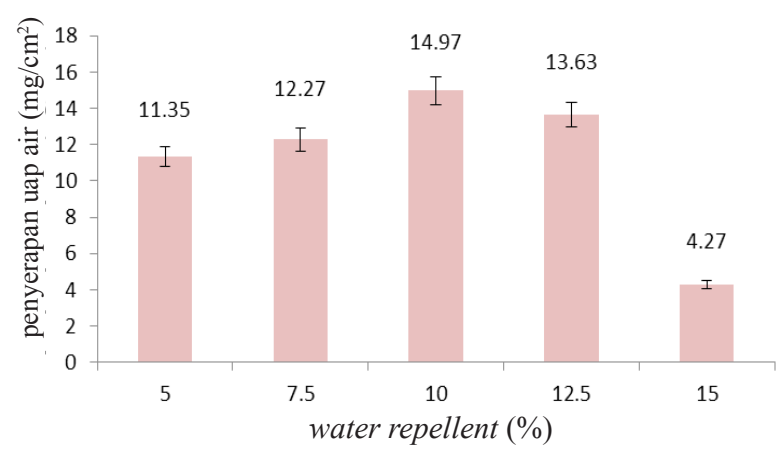

Gambar 6. Penyerapan air kulit atasan sepatu samak nabati dengan perbedaan kadar water repellent. 

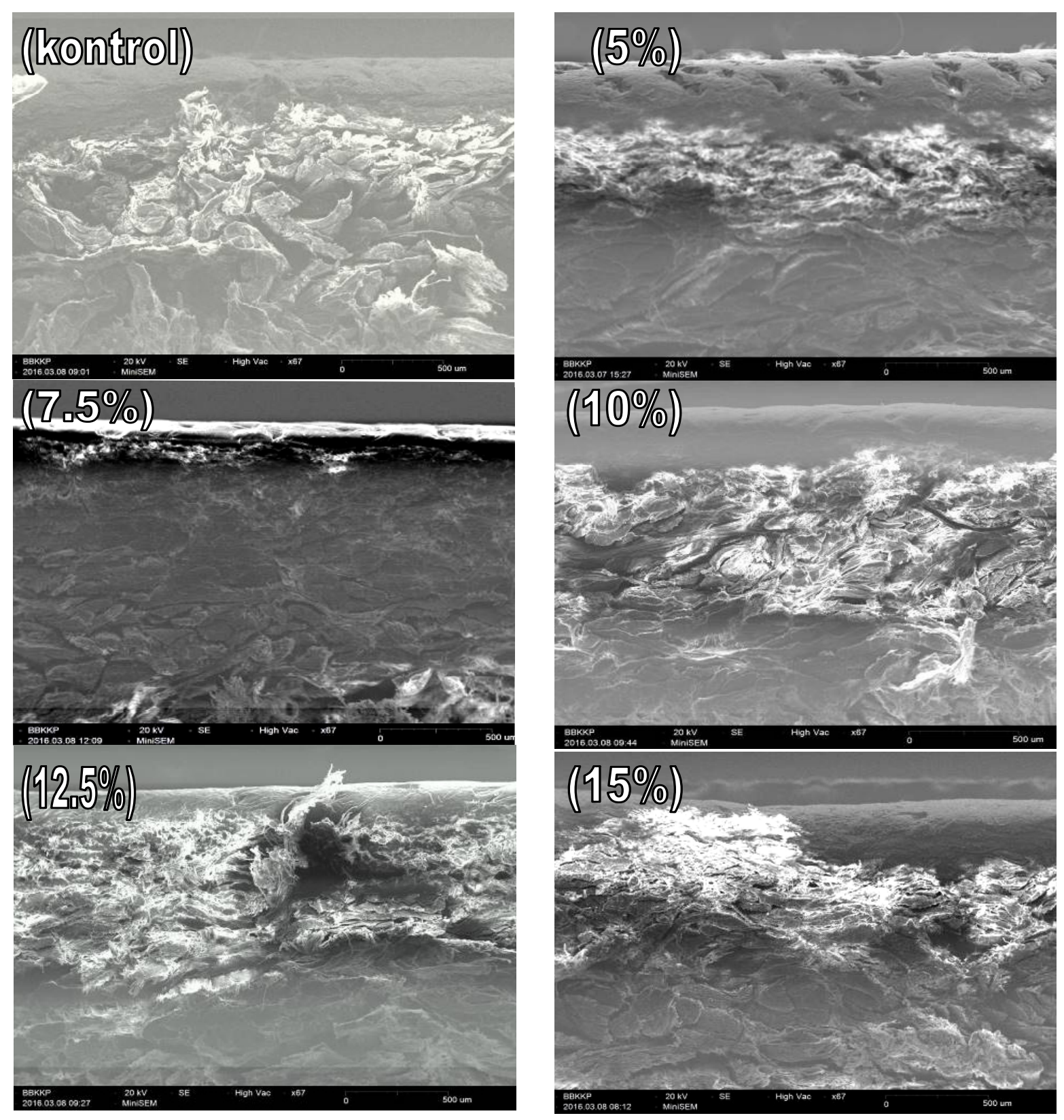

Gambar 7. SEM penampakan melintang kulit atasan sepatu samak nabati dengan variasi kadar water repellent, dengan perbesaran $67 \mathrm{x}$.

$12 \%$ kemungkinan disebabkan oleh adanya penetrasi yang tidak menentu bahan water repellent pada ikatan-ikatan jaringan kulit sehingga menurunkan breathability (Jankauskaite et al., 2014).

Dari grafik terlihat bahwa kenaikan penggunaan water repellent akan menaikkan penyerapan uap air, namun pada penggunaan $15 \%$ menunjukkan adanya penurunan penyerapan.

\section{Morfologi Kulit Atasan Sepatu}

Hasil analisis dari mikroskop elektron (Gambar 7) terlihat bahwa struktur nerf berserat, cukup bersih dan sedikit ada kecacatan, khususnya pada contoh dengan water repellent $5 \%$, pori-pori rambut terlihat jelas. Pada contoh dengan perlakuan water repellent $7,5 \%$ terlihat bahwa water repellent yang digunakan melapisi permukaan seratnya sehingga menutup pori rambut. Pada contoh dengan water repellent $12,5 \%$ terlihat adanya penimbunan dari bahan dimungkinkan karena water repellent kurang tersebar merata pada seluruh serabut kulit, morfologi kulit terlihat homogen dan padat. 


\section{KESIMPULAN}

Dari hasil penelitian dapat disimpulkan bahwa pengaruh water repellent pada pembuatan kulit atasan sepatu dengan samak mimosa akan memberikan pengaruh pada sifat-sifat fisis kulit, penurunan dalam sifat penyerapan air dari $77,6 \%$ pada penggunaan water repellent $5 \%$ menjadi $65,39 \%$ pada penggunaan water repellent $15 \%$, penurunan kuat sobek dari $41,64 \mathrm{~kg} / \mathrm{cm}$ menjadi $20,05 \mathrm{~kg} / \mathrm{cm}$ berturut-turut dengan water repellent 5 dan $15 \%$, untuk kuat tarik dari 227,10 menjadi $163,53 \mathrm{~kg} /$ $\mathrm{cm}^{2}$ dan kemuluran dari 57,11 menjadi 49,68\% masing-masing untuk water repellent berturutturut 5 dan $15 \%$, sedang untuk kuat bengkuk dan WVA tidak ada perubahan yang signifikan, untuk WVP maksimum terjadi pada penggunaan water repellent $12,5 \%$. Hasil SEM menunjukkan adanya water repellent akan membentuk lapisan-lapisan pada serat kulit yang akan menghambat penyerapan kulit.

\section{UCAPAN TERIMA KASIH}

Terima kasih kami ucapkan kepada Kepala Balai Besar Kulit, Karet, dan Plastik dan Kepala Bidang Sarana Riset dan Standardisasi atas izin menggunakan fasilitas yang ada di Balai Besar Kulit, Karet, dan Plastik sehingga penelitian ini dapat diselesaikan.

\section{DAFTAR PUSTAKA}

Ali, S. B., Haroun, H. E., \& Musa, A. E. (2013). Haraz bark powder extract for manufacture of nappa upper leather as alternative retanning agent. Journal of Forest Products \& Industries, 2(5), 25-29.

BSN (Badan Standardisasi Nasional). (2009). Standar Nasional Indonesia SNI 4901:2009:Kulit bagian atas alas kaki-kulit nappa. Jakarta, Indonesia: BSN.

Castell, J., Sorolla, S., Jorba, M., \& Aribau, J. A. B. (2013). Tara (Caesalpinia spinosa): The sustainable source of tannins for innovative tanning processes. Journal of the American Leather Chemists Association, 108(6), 221-230.

Covington, A. D. (2009). Tanning chemistry: The science of leather. Cambridge, UK: The Royal Society of Chemistry.

Jankauskaite, V., Gulbiniene, A., Jiyembetova, I., Sirvaityte, J., Urbelis, V., \& Mickus, K. V. (2014). Comparable evaluation of leather waterproofing behaviour upon hide quality. II. Influence of finishing on leather properties. Materials Science, 20(2), 165-169. http://dx.doi.org/10.5755/j01. $\underline{\text { ms.20.2.2339 }}$
Koloka, O., \& Moreki, J. (2011). Tanning hides and skins using vegetable tanning agents in Hukuntsi sub-district, Botswana. Journal of Agricultural Technology, 7(4), 915-922.

Li, Y., Gao, D. G., \& Ma, J. Z. (2011). Synthesis of vinyl polymer / $\mathrm{ZnO}$ nano composite and its application in leather tanning agent. Journal Materials Science Forum, 694, 103-107. http://dx.doi.org/10.4028/ www.scientific.net/MSF.694.103

Mahdi, H., Palmina, K., Gurshi,A., \& Covington, A. D. (2009). Potential of vegetable tanning materials and basic aluminum sulphate in Sudanese leather industry. Journal of Engineering Science and Technology, 4(1), 20-31.

Mazumder, D., Santosh, B., \& Pratip, B. (2006). Study on leaching of pollutants from vegetable tanning residue. Journal of Environmental Science \& Engineering, 48(3), 225-230.

Musa, A. E., \& Aravindhan, B. M. J. R. R. (2011). Henna-aluminum combination tannage: A greener alternative tanning system. Journal of the American Leather Chemists Association, 106, 179-211.

Mutlu, M. M., Crudu, M., Maier, S. S., Deselnicu, D., Albu, L., Gulumser, G., \& Tosun, C. C. (2014). Eco-leather: Properties of chromium-free leathers produced with titanium tanning materials obtained from the wastes of the metal industry. Ekoloji, 23(91), 83-90.

Nashy, E. H. A., Hussein, A. I., \& Essa, M. M. (2010). Retanning agents for chrome tanned leather based on emulsion nano-particles of styrene/butyl acrylate copolymers. New York Science Journal, 3(11), 13-21.

Nasr, A. I., Abdelsalam, M. M., \& Azzam, A. H. (2013). Effect of tanning method and region on physical and chemical properties of Barki sheep leather. Egyptian Journal of Sheep and Goat Sciences, 8(1), 123-130.

Ozgunay, H., Colak, S., Mutlu, M. M., \& Akyuz, F. (2007). Characterization of leather industry wastes. Polish Journal of Environmental Studies, 16(6), 867-873.

Prayitno, P. (2014). Penelitian Pembuatan Kulit Jaket Ramah Lingkungan menggunakan Bahan Penyamak Nabati. In Prosiding Seminar Nasional Kulit, Karet, dan Plastik ke-3 Yogyakarta, 29 Oktober 2014 (pp. 67-83).

Ramanujam, R. A., Ganesh, R., \& Kandasamy, J. (2010). Wastewater treatment technology for tanning industry. Encyclopedia of Life Support Systems (EOLSS), 1-22.

Widari, W., Rambat, R., \& Suparti, S. (2013). Pembuatan kulit atasan sepatu bebas krom. Majalah Kulit, Karet, dan Plastik, 29(2), 99-104. http://dx.doi. org/10.20543/mkkp.v29i2.197

Yan, L., Chen, Y., Fan, H., Peng, B., \& Shi, B. (2008). A novel nano-SiO 2 tannage for making chrome- 
free leather. Journal of the Society of Leather

Technologists and Chemists, 92(0), 252-257. 